\title{
Perceived Health Consequences of Indiscriminate Waste Disposal by the Market Women
}

\author{
Kalesanwo Olufemi O., Ph.D \\ kalepay@yahoo.com \\ Oke Kayode, Ph.D \\ Kayodeoke734@yahoo.com \\ Okufuwa Olusile A., M.Ed \\ Department of Sports Science and Health Education \\ Faculty of Education, Olabisi Onabanjo University, Ago-Iwoye, Ogun-State \\ Email: olusileodukoya@yahoo.com
}

\section{Doi:10.5901/mjss.2013.v4n14p553}

\section{Abstract}

Indiscriminate waste disposal habit has caused health related diseases. This study was carried out to investigate the perceived health consequences of indiscriminate waste disposal by the market women of ljebu - Ode Township. A descriptive survey design was used for the study while market women's perception of health consequences of indiscriminate waste disposal was the main objective of this study. A total of 500 participants were drawn from the population as sample size for the study while stratified sampling technique was used to sectionalize the services and products being produced or sold by the market women. Simple random sampling was used to select 300 respondents from Ita - Osu market and 200 respondents from Oke Aje market. The instrument used for data collection was a self-developed Indiscriminate Waste Disposal and Health Consequences Questionnaire (IWDHCQ) with a reliability index of 0.83. Inferential statistics of chi-square was used to analyse the data at 0.05 level of significance. All the five hypotheses tested were not accepted which revealed that market women significantly perceived Lassa fever, Typhoid fever, Malaria fever, Food Contamination, Water Source Contamination as health consequences of indiscriminate waste disposal. Based on the findings, some recommendations were recommended to government, policy makers, health authorities and market women among were: health campaign on better waste disposal methods to market women, educating the market women in order to appreciate the health problems associated with indiscriminate waste disposal and the enforcement of sanitation laws by the appropriate authorities, just to mention a few.

Keywords: Health Consequences, waste disposal, Indiscriminate waste disposal, and environmental sanitation.

\section{Introduction}

In order to protect man's environment and promote his health, waste disposal and management should be more aggressively addressed in our society. Waste is more easily recognized than defined. Something can become waste when it is no longer useful to the owner or it is used and fails to fulfill its purpose (Gaurlay, 2012). Solid waste according to Milter (2008) is any useless unwanted or discarded materials that are not liquid or gas. It is a great mixture of substances including fine dust, metal, glass, paper and cardboards, textiles, vegetable materials and plastic characterise solid waste (Simmens, 2001).

Wastes as opined by Oluwade (2009) are refuse (empty containers, papers rubbish e.t.c) sewage (faeces, water urine) and industrial waste (chemical nuclear) that result from the manufacturing of certain substances, materials and equipment. The interaction organisms and their environment leads to the generation of waste. Waste is non-beneficial materials discarded; therefore all these have to be properly disposed.

Refuse are waste materials that have been thrown away. The statutory definition of refuse is not based on the physical form of materials,

that is, whether or not it is solid, as opposed to liquid or gas but on the fact that the material is a waste. The United State Environmental Protection Agency (2011) defines solid refuse as any garbage, refuse, sludge from a waste water 
treatment plant, water supply treatment plant or air deed material, including solid, liquid, semi-solid or contaminated gaseous material and agricultural operation and from community activities. Human has always produced waste that included not only the discarded bones of animals slaughtered for food.

Refuse according to Clesceri (2008) can be divided into two main groups these are: that which is mainly dry and can be put directly in the dustbins and that which is liquid and may be drained away through pipes. The dry household refuse can be disposed using galvanized iron or plastic bins having a well - fitted lids and two handles for easy transportation. The bins are placed away from the kitchen or the back door. The only waste that should be put in this bin are dusts, waste papers, leaves, nylon or cellophane wrappers tins and bottles. The other type of wastes includes faeces, urine and water wastes from our kitchen and bathroom.

United Nations Environmental Programme (2010), states that human beings are faced with the problem of the disposal of waste. In villages people have a lot of land at their disposal. Organic matters can be thrown away and they are allowed to decompose on these land. However, in cities and towns, people run the risk of being infected with diseases due to limited land to spare for refuse.

The effects of indiscriminate waste disposal in man are numerous. The flora or fauna on the environment in form of health problems from convulsion, dermatitis, irritation of nose, throat, anemia, skin burns, chest pains, blood disorders, stomach aches, vomiting, diarrhea, lungs cancer to death. Other health effects includes flies which carry germs on their bodies and legs and also excrete them, mosquitoes breed in stagnant water, blocked drains in favourable location (Freeze and Cherry, 2006).

Some residents burn their refuse, while others indiscriminately burry it. Indiscriminate disposal, burning and burying of refuse pose major environmental and health threats through soil and water which put the entire eco-system of an area in danger. The contamination of waste cause severe problems for human and animals alike. The major environmental effects include air pollution which includes odour, smoke, noise, dust and so on. The rapid growth of cities in the developing world in recent decades has resulted in increased consumption of resources to meet the growing demands of urban population and industry. This situation leads to generation of large amount of waste.

Seventy to eighty percent of refuse in African cities are disposed of by dumping in open spaces, water bodies and surface drains as a result of inadequate infrastructure and ignorance of inhabitants (United Nations Environmental Programme, 2010). Indiscriminate disposal of waste is detrimental to health because it creates unsanitary environment that have adverse impacts for urban residents where sanitary facilities are scarce and the household refuse are not disposed properly, compound the health hazards. (Oluwade, 2009).

Nigerian cities have been described as some of the dirtiest, most unsanitary and the least aesthetically pleasing in the world (Gomez and Nakat 2007). It has been suggested that the quantity of wastes generated in the state is proportional to population size. As population increases so also waste generated also increases. When materials are stored in a place or container before it is being transported for the point of storage, the point of disposal, this can then be dumped on land at a tip either in engineered and hygienic way or indiscriminately disposed. A healthy man is a wealthy man; if a nation is healthy the nation will be wealthy. A healthy man brings about a wealthy man which brings the expression "health is wealth."

The dangers of indiscriminate waste disposal are all around the nooks and crannies of the country and the effects constitute nothing but negative effects to the inhabitants.

The rate of health retrogression that are waste disposal related is so alarming as it can lead to: health hazard i.e disease; environmental hazard; accident on our environment; social effects, and economic effects.

\section{Objective of the Study}

The objective of this study was to find out the perceived health consequences of indiscriminate waste disposal by the market women in ljebu-Ode Township.

\section{Statement of the Problem}

The rapid growth of cities in the developing world in recent decades has resulted in increased consumption of resources to meet the growing demands of urban populations and industries and this situation leads to the generation of large amount of wastes in cities and major towns.

The main cause of the problem of Nigerian cities poor environmental conditions according to Sule (2011) can be ascribed to improper disposal and management of wastes and lack of seriousness in the enforcement of rules of waste 
disposal. Due to weak institutional capacities and lack of resources, both human and capital waste management and sanitation in many third world cities, particularly in Africa are in very deplorable conditions.

Indiscriminate disposal of organic waste is detrimental to health because it creates unsanitary environment that have adverse effects for urban residents. Where sanitary facilities are scarce, household solid wastes also tend to be mixed with fecal matter, further compounding the health hazards (Kiellen, 2011). People's apathetic and lackadaisical attitudes towards matters relating to personal hygiene and environmental cleanliness, of which waste management in general is a focal point that can not be whisked away.

A considerable larger percentage of inhabitants of ljebu-Ode township and adjoining villages patronize three major markets in ljebu-Ode, either to buy, sell or render services. These markets are flanked by residential buildings from all fronts. The non-existence of designated refuse dump sites in these markets, notably, the Ita-Osu and Oke-Aje has caused markets men and women to be disposing their wastes indiscriminately. Places meant for motor parks, exit gates and gutters for drainage have been converted into refuse dump sites. Many of these waste including sachet water nylon, rotten foods, discarded stationery items, broken plastics and bottles among several others, have found their ways back to nearby shops and passage ways when wind blows and rain falls. Rodents, flies, maggots are common sights in these markets as well as foul odour that can cause nausea. It is therefore imperative to find out from the market women of these popular markets about their perception of indiscriminate waste disposal and it's health consequences on the health consumers. This is the gap that this study is out to fill.

\section{Research Hypotheses}

The following research hypotheses were formulated and tested

1. Lassa fever will not be significantly perceived by market women as a health consequence of indiscriminate waste disposal in ljebu-Ode Township.

2. Typhoid fever will not be significantly perceived by market women as a health consequence of indiscriminate waste disposal in ljebu-Ode Township.

3. Malaria fever will not be significantly perceived by market women as a health consequence of indiscriminate waste disposal in ljebu-Ode Township.

4. Food contamination will not be significantly perceived by market women as a health consequence of indiscriminate waste disposal in ljebu-Ode Township.

5. Water source contamination will not be significantly perceived by market women as a health consequence of indiscriminate waste disposal in ljebu-Ode Township.

\section{Significance of the Study}

The market environment in which market women trade and undertake most of their activities can impact on their health and quality of lives. This study may therefore create awareness and appreciation of the values of creating healthy environment among market women. It may therefore be a significant contribution to the field of environmental health education.

Findings of this study may provide the government at both state and local levels where this study will be conducted, the need to ensure that wastes disposal are given urgent and prompt attention. Healthy and fit populace will contribute to the development of the society hence, this study may be an eye-opener to the government by providing facilities to improve on the waste disposal and management of urban cities.

This study may help to enlighten the private sectors who have the where withal to present a proposal to the local and state governments on the need to involve private sector participation in the effective management of wastes in Urban cities of the country.

This study may be of significance to the consumers that patronize these markets as they may also be educated on the inherent dangers posed by heaps of waste and the need to be more careful.

The environmental health officers in ljebu-Ode local government may see this study as a wake-up call to their duty, and thus ensure that the wastes generated in these markets are properly managed in order to prevent outbreak of diseases.

The findings of this study will remain significant to the field of knowledge in environmental health education and waste management.

The policy makers may find this study useful in the ministries of health and environment. 


\section{Methodology}

The researchers employed descriptive survey research design to carry out the study. The design was considered appropriate for this study because it helps to provide a wide base information and data collection to answer the research hypotheses.

The target population for this study comprised all market women in ljebu-Ode Township.

\section{Sample and Sampling Technique}

The sample size for this study comprised 500 (five hundred) market women in ljebu-Ode township. The participants were selected using stratified sampling techniques i.e grouping through the sections of the products and services they render thus:

$\begin{array}{llll}\text { a. Ita }- \text { Osu } & 300 & \text { b. Oke -Aje } & 200 \\ \text { Food items sellers } & 100 & \text { Food items sellers } & 50 \\ \text { Provision sellers } & 100 & \text { Provision sellers } & 50 \\ \text { Cloth sellers } & 50 & \text { Cloth sellers } & 50 \\ \text { Stationeries sellers } & 50 & \text { Stationeries sellers } & 50\end{array}$

The choice of the two (2) markets was based on the fact that they are modern markets that supposed to have functional waste disposal facilities/equipment.

\section{Research Instrument}

The research instrument used for data collection was a self structured and validated questionnaire. The questionnaire consisted of 2 sections: sections A and B. Section A sought information on demographic data of participants while section $B$ contains items used to elicit information from the participants on the variables of this study.

The questionnaire was a modified four (4) points Likert model scales of Agree (A) Strongly Agree (SA) Disagree (D), Strongly Disagrees (SD)

\section{Validity and Reliability of the Instrument}

The research instrument for this study was validated through face and content validity.

The reliability of the instrument was ensured using test re-test method. The questionnaire was administered on ten (10) market women and after one week, the instrument was re-administered to the same group. The two sets of data were subjected to Pearson Product Moment Correlation Coefficient ( $r$ ) to establish its reliability level. The reliability coefficient stood at 0.83 .

\section{Data Collection}

The data for this study were collected through the use of a validated questionnaire administered by the researchers and three research assistants to the participants. Fourteen days (two weeks) were used in collecting the data.

\section{Data Analysis}

The data obtained from the questionnaires were collated and analyzed using inferential statistics of chi-square.

11.1 Hypothesis 1: Lassa fever will not be significantly perceived by market women as a health consequence of indiscriminate waste disposal in ljebu - Ode township. 
Table 1: $\bar{X}^{2}$ table of Lassa fever as health consequence of indiscriminate waste disposal

\begin{tabular}{|c|c|c|c|c|c|c|c|c|}
\hline Items & $\mathrm{SA}$ & $A$ & D & SD & Total & $\mathrm{DF}$ & $\mathrm{X} 2$ & Sig \\
\hline 1 & 185(117.0) & 201(153.8) & 63(134.0) & 5193(95.3) & $500(500.0)$ & \multirow{5}{*}{3} & 264.6 & 0.00 \\
\hline 2 & $65(117.0)$ & 91(153.8) & 184(134.0) & 16093(95.3) & $500(500.0)$ & & & \\
\hline 3 & 134(117.0) & 180(153.8) & 109(134.0) & 7793(95.3) & $500(500.0)$ & & & \\
\hline 4 & $84(117.0)$ & 143(153.8) & $180(134.0)$ & $93(95.3)$ & $500(500.0)$ & & & \\
\hline Total & $468(468.0)$ & $615(615.0)$ & $536(536.0)$ & $381(381)$ & $2000(2000.0)$ & & & \\
\hline
\end{tabular}

The table 1 above shows the chi-square value $(264.6)$ at df3 which is significant at 0.05 , $(p<0.05)$. It follows that Lassa fever was significantly perceived by market women as health consequence of indiscriminate waste disposal in ljebu-Ode township, therefore the hypothesis that says Lassa fever will not be significantly perceived by market women as health consequence of indiscriminate waste disposal in ljebu - Ode township is hereby not accepted.

11.2 Hypothesis 2: Typhoid fever will not be significantly perceived by market women as a health consequence of indiscriminate waste disposal in ljebu-Ode Township.

Table 2: $\bar{X}^{2}$ table of Typhoid fever as health consequence of indiscriminate waste disposal.

\begin{tabular}{|c|c|c|c|c|c|c|c|c|}
\hline Items & SA & A & $\mathrm{D}$ & SD & Total & $\mathrm{DF}$ & $\mathrm{X} 2$ & Sig \\
\hline 5 & $138(121.0)$ & 196(156.3) & $107(139.8)$ & $59(83.0)$ & $500(500.0)$ & \multirow{5}{*}{3} & 107.9 & 0.00 \\
\hline 6 & 103(121.0) & 179(156.3) & 122(139.8) & $96(83.0)$ & $500(500.0)$ & & & \\
\hline 7 & 159(121.0) & 136(156.3) & 127(139.8) & $78(83.0)$ & $500(500.0)$ & & & \\
\hline 8 & $84(121.0)$ & 114(156.3) & 203(139.8) & $99(83.0)$ & $500(500.0)$ & & & \\
\hline Total & $484(484.0)$ & $625(625.0)$ & $559(559.0)$ & $332(332.0)$ & $2000(2000.0)$ & & & \\
\hline
\end{tabular}

The table 2 above shows a chi-square value (107.9) at df3 which is significant at 0.05 , ( $p<0.05)$. It follows that Typhoid fever was significantly perceived by market women as environmental health consequence of indiscriminate waste disposal in ljebu - Ode township. The hypothesis that says typhoid fever will not be significantly perceived by market women as health consequence of indiscriminate waste disposal in ljebu Ode township is hereby not accepted.

11.3 Hypothesis 3: Malaria fever will not be significantly perceived by market women as a health consequence of indiscriminate waste disposal in ljebu - Ode township.

Table 3: $\bar{X}^{2}$ table of Malaria fever as health consequence of indiscriminate waste disposal

\begin{tabular}{|c|c|c|c|c|c|c|c|c|}
\hline Items & SA & A & D & SD & Total & DF & $\mathrm{X} 2$ & Sig \\
\hline 9 & 135(117.8) & 154(145.5) & 118 (139.3) & 93 (96.3) & $500(500.0)$ & \multirow{5}{*}{3} & 40.4 & 0.00 \\
\hline 10 & 115(117.8) & $183(145.5)$ & $113(139.3)$ & $89(96.3)$ & $500(500.0)$ & & & \\
\hline 11 & $107(117.8)$ & $120(145.5)$ & 174(139.3) & $99(96.3)$ & $500(500.0)$ & & & \\
\hline 12 & 119(117.8) & $125(145.5)$ & $152(139.3)$ & $104(96.3)$ & $500(500.0)$ & & & \\
\hline Total & 476 (476.0) & $582(582.0)$ & $557(559.0)$ & $385(385.0)$ & $2000(2000.0)$ & & & \\
\hline
\end{tabular}

The table 3 above shows a chi-square value $(40.0)$ at df3 which is significant at 0.05 , $(p<0.05)$. It follows that malaria fever was significantly perceived by market women as environmental health consequence of indiscriminate waste disposal in ljebu - Ode township. The hypothesis that states malaria fever will not be significantly perceived by market women as environmental health consequence of indiscriminate waste disposal in ljebu - Ode township is hereby not accepted.

11.4 Hypothesis 4: Food contamination will not be significantly perceived by market women as a health consequence of indiscriminate waste disposal in ljebu - Ode township. 
Table 4: $\bar{X}^{2}$ table of Food contamination as health consequence of indiscriminate waste disposal.

\begin{tabular}{|c|c|c|c|c|c|c|c|c|}
\hline Items & SA & $A$ & $\mathrm{D}$ & SD & Total & DF & $\mathrm{X} 2$ & Sig \\
\hline 18 & $150(124.7)$ & $159(152.0)$ & $118(122.7)$ & 76(108.3) & $500(500.0)$ & \multirow{4}{*}{3} & 113.4 & 0.00 \\
\hline 19 & $81(124.7)$ & $200(152.0)$ & 102(122.7) & 79(108.3) & $500(500.0)$ & & & \\
\hline 20 & $143(124.7)$ & $97(152.0)$ & $148(122.7)$ & $170(108.3)$ & 500 & & & \\
\hline Total & 351 (351.0) & $456(456.0)$ & $368(368.0)$ & $325(108.0)$ & $1500(1500.0)$ & & & \\
\hline
\end{tabular}

From the table 4 above, the chi-square value $(113.4)$ at $d f 3$ is significant at $0.05,(p .<0.05)$. It follows that food contamination was significantly perceived by market women as health consequence of indiscriminate waste disposal in ljebu - Ode township. The Hypothesis that states food contamination will not be significantly perceived by market women as environment health consequence of indiscriminate waste disposal in ljebu - Ode Township is hereby not accepted.

11.5 Hypothesis 5: Water source contamination will not be significantly perceived by market women as a health consequence of indiscriminate waste disposal in ljebu - Ode township.

Table 5: $\bar{X}^{2}$ table of Water contamination as health consequence of indiscriminate waste disposal

\begin{tabular}{|c|c|c|c|c|c|c|c|c|}
\hline Items & SA & A & D & SD & Total & DF & $\mathrm{X} 2$ & Sig \\
\hline 21 & 150(124.7) & $153(149.0)$ & $123(134.0)$ & 74(92.3) & $500(500.0)$ & \multirow{4}{*}{3} & 119.0 & 0.00 \\
\hline 22 & 81(124.7) & 98(149. & 185(134.0) & 136(92.3) & $500(500.0)$ & & & \\
\hline 23 & $143(124.7)$ & $196(149.0)$ & 94(134.0) & $67(92.3)$ & $500(500.0)$ & & & \\
\hline Total & $374(374.0)$ & $447(447.0)$ & $402(402.0)$ & $277(277.0)$ & $1500(1500.0)$ & & & \\
\hline
\end{tabular}

From the table 5 above, the chi-square value (119.0) at df3 is significant at $0.05,(p<0.05)$. It follows that water source contamination was significantly perceived by market women as environmental health consequence of indiscriminate waste disposal in ljebu - Ode Township. The hypothesis that says water contamination will not be significantly perceived by market women as health consequence of indiscriminate waste disposal in ljebu - Ode township is hereby not accepted.

\section{Discussion of Findings}

\subsection{Hypothesis 1}

The findings in Hypothesis one corroborates the position of Jegede (2004) who stated that where refuse is indiscriminately dumped, it can become injurious to both man and animals as it can find its way to the water bodies, causing rodent infestation and bringing about the spread of diseases like plague, Lassa fever among others.

\subsection{Hypothesis 2}

Hypothesis two findings was buttressed by Gomez and Nakat (2007) who opined that water pollution can arise where solid waste is disposed of indiscriminately; that is, where waste is not properly disposed of, it can cause underground and water pollution with attendant typhoid germs and other micro organism which are very harmful to humans with the most common complications being constant headache, perforation of the intestinal walls, to mention, but a few.

\subsection{Hypothesis 3}

The third hypothesis revealed that malaria fever was significantly perceived by market women as health consequence of indiscriminate waste disposal, thereby, affirming the position of Oluwade (2009) that indiscriminate disposal of refuse aids the wide spread of infectious diseases as a result of flies infestation; for instance mosquitoes can bring about the spread of malaria which is known to be one of the ten most prevalent and deadly diseases in the world.

\subsection{Hypothesis 4}

Hypothesis four reveals that food contamination was significantly perceived by market women as health consequence of 
indiscriminate waste disposal. These findings corroborates the position of Gomez and Nakat (2007) that the main agents of waste producer are stores, tea stalls, business premises, restaurants, markets, food vendours and motor parks which can be found in major markets in ljebu - Ode. These sources, according to Gomez and Nakat (2007) produce waste that can contaminate food preparation and food sources.

\subsection{Hypothesis 5}

The fifth hypothesis found that water source contamination was significantly perceived by market women as a health consequence. Ojo (2010) reinforces these findings, expressing that indiscriminate waste disposal result into environmental degradation which in turn lends to a phenomenal increase in the volume and diversity of hazardous waste and the consequent contamination of water. This contamination of water source result in serious illness and in some cases, death. Ojo further explained that indiscriminate waste disposal can result in contamination of surface water and ground water, creating potential for considerable health risks for the people.

\section{Conclusion and Recommendations}

This study concludes that market women significantly perceived Lassa fever, Typhoid fever, Malaria fever, Food Contamination, and Water Source Contamination as health consequences of indiscriminate waste disposal.

Some of the respondents acknowledged that they were not acknowledgeable of the health consequences of indiscriminate waste disposal.

\subsection{Recommendations}

From the findings of this study, it is recommended that:

1. Various women organizations should step-up campaign strategies that will educate the women folk in markets about the attendant health consequences of indiscriminate waste disposal.

2. ljebu - Ode local government should be more alive to their roles, especially, the environmental sanitation issues in these markets should be given due attention.

3. Also, government should ensure that designated waste points are increased in order to prevent littering of the floor by consumers and market women.

4. The environmental health officers should ensure that the penalties for indiscriminate waste disposal are enforced in order to ensure safe and clean environment.

5. Market day sanitation to be observed at least once in a week as is being done in Lagos and Oyo states of Nigeria.

6. The Market Women Association should employ cleaners who will ensure effective cleaning of the market.

7. Local Government Health Education unit should organize seminars and health talks for the market women through their associations. This should be done at least twice in three months.

8. Environmental Health Officers should be more functional in their duties.

\section{References}

Adediji, A. \& Ajibada L. T. (2005). Quality of well water in Ede Area South Western, Nigeria, Ibadan. Alkijah W. (2002). Essentials of community Health; Primary health care and management. Benin: Ambik press.

Bassey F.S. (2002). The need to develop a variable health education curriculum for Nigerian schools. In Manasaray A. and Osokoya I. O. (eds). Curriculum Development at the Turn of the century. The Nigeria experience. Ibadan. The department of Teachers Education.

Clesceri I. S. (2009). Standard waste water (17 th ed) Chicago American Public Health Association Publishers.

Cointreus S (2002). Basic Environmental health. London: Oxford University Press.

Delano, G. E (1999). Pocket book of common terms on Health. Ibadan: Spectrum Books.

Freeze R. A. \& Cherry, J. A. (2006). Ground water (3rd ed). New York: Prentice Hall incorporations.

Gaurlay, Y. A. (2012). Waste Generation and Management Techniques. Contemporary Issues in Environmental Studies, pp. 112 - 115.

Gomez J. O. \& Nakat, A. C. (2007). Community participation in water and sanitation water and sanitation water, New York: John Wiley.

Hobsen E. (1999). The theory and practice of public Health London: Oxford University Press.

Kiellen, J. C. (2011). Geomorphology In Environmental Management: An Introduction. Oxford: University Press.

Lawal S.A \& Aniab T. (1999). Community Health and Environmental service. London: Hodder and Stoughton. 
Milter, R. V. (2008). Environmental Health, London: Biddles Ltd, Guildford and King's Lynn.

Mishra, S. B. \& Kayastra, R. P. (2002). Solid waste management. HHp:// www/gov.ab.ca/envlinfo/infocentre/publishing.Cfon. Retrieved on $11^{\text {th }}$ January, 2012.

Moronkola O. A \& Okanlawon F. A (2003). Fundamental of public and community Health education, Ibadan: Royal people.

Oluwade P. A. (2009). A guide to tropical environmental health and Engineering, Lagos. A publication of Nigerian Istitute of Social and economic Research.

Ojo, M. (2010). Waste management actions in cities. Ibadan Macmillan.

Oreyome M. K. (2001). Reach the wed of life. Daily sketch. June 5, p 22.

Park, K. (2009). Preventive and social Medicine. Jabalpur: Banarsidas Bhanot.

Philips, T. A. (2009). A New Tropic Health Science, Lagos: Macmillan lucas Anthony publication.

Salako, A. A. (2008). Environmental health. Journal of Environmental Health, 2, 23 - 28.

Simmens, D. L. (2001). Protecting the Environmental workers, Bombay: Society for the study of Environmental Studies Publications.

Sule, A. B. (2011). Management of Environments in Africa: A Handbook and References, Lagos: Greenwood Publishing Group Inc.

United Nations Environmental Programme (2010). www.un. In //environmental program/activity/publications/Africa. Retrieved on $12 / 08 / 2012$.

United States Environmental Protection Agency. (2011). http:// www.usepa.org.Retrived on 08/08/2012.

WHO (1999). Community Emergency Preparedness: a manual for managers and policy makers.

WHO (2000). www. Who.avert.org/wordstats.ht. Retrieved on $11^{\text {th }}$ May, 2012.

WHO (2006). The World Health Report (2006)

WHO (2006). www.wtw.int/Global/Atlas/PDF Factory. Retrieved on 25th August, 2012. 